\title{
Analisis Konsumsi Daging Sapi Di Provinsi Papua Barat
}

\section{Analysis of Beef Consumption in West Papua Province}

\author{
T.W. Widayati ${ }^{1}$, S. Widodo ${ }^{2}$, Masyhuri ${ }^{2}$, dan A. Suryantini ${ }^{2}$ \\ ${ }^{1}$ Fakultas Peternakan Perikanan dan Kelautan Universitas Negeri Papua \\ J1. Gunung Salju, Amban. Manokwari. \\ ${ }^{2}$ Fakultas Pertanian Universitas Gadjah Mada \\ Jl. Flora, Bulaksumur. Yogyakarta, 55281 \\ e-mail: trieswd@yahoo.com
}

(Diterima: 4 Januari 2011; Disetujui: 18 Mei 2011)

\begin{abstract}
The study aims to determine the level of beef consumption and the factors that influence the consumption of beef in West Papua. The data used in this study are monthly time series data of BPS, sourced from all districts in the province of West Papua from 1990 to 2004. Data were analyzed by using multiple linear regression equation by Ordinary Least Square method. The results showed that the average beef consumption per capita per year for people of West Papua is $0.79 \mathrm{~kg}$. The increasing of population and income per capita affected the increasing of beef consumption significantly. Increasing the price of chicken meat, pork prices and the price of rice has significant effect of reducing domestic consumption of beef. Increasing the price of tuna, squid and sweet potatoes have a significant effect in increasing of the domestic consumption of beef.
\end{abstract}

Keywords: beef consumption, time series, Ordinary Least Square

\section{PENDAHULUAN}

Untuk memenuhi kebutuhan konsumsi daging sapi di Indonesia masih memerlukan impor, yang volumenya terus meningkat. Permintaan untuk periode 2000-2010 diperkirakan mengalami laju peningkatan sebesar 5\% per tahun, sedangkan penawaran daging domestik diperkirakan mengalami penurunan dengan laju $-0,13 \%$ per tahun (Ilham et al., 2002). Dengan demikian terjadi kesenjangan yang semakin lebar antara permintaan dan penawaran (Setiyono et al., 2007). Pada tahun 2006, tingkat konsumsi daging sapi di Indonesia diperkirakan 399.660 ton, atau setara dengan 1,70 - 2 juta ekor sapi potong (Suryana, 2009). Hal ini berkaitan dengan elastisitas pendapatan masyarakat terhadap permintaan daging, yang menurut Direktorat Jenderal Peternakan (1999) dapat disebabkan oleh adanya urbanisasi (Soejana, 2005) .

Peningkatan konsumsi daging sapi terjadi pula di Provinsi Papua Barat. Berdasarkan data BPS dan Dinas Pertanian dan Kehutanan Provinsi Papua Barat (2009), konsumsi daging sapi yang dinyatakan dalam besarnya jumlah pemotongan sapi selama kurun waktu 2004 hingga 2008 mengalami kenaikan sebesar $114,38 \%$, atau sebesar $22,8 \%$ tiap tahun. Konsumsi masyarakat terhadap suatu komoditi pangan pada hakikatnya didasarkan untuk mencapai kepuasan. Dalam pencapaian kepuasan tersebut konsumen dibatasi oleh beberapa kendala antara lain pendapatan dan harga barang baik harga barang itu sendiri, harga barang subtitusi dan harga barang komplementer dari komoditi tersebut. Dari hasil penelitian Hennebery dan Hwang (2007) terhadap permintaan daging di Korea Selatan menunjukkan bahwa semakin modern suatu masyarakat, disertai dengan peningkatan income akan berkecenderungan memiliki pola konsumsi tipe westernlife. Masyarakat akan memilih beberapa produk daging sebagai variasi konsumsi dibanding produk nabati. Ditambahkan pula oleh Witt (2001) bahwa seiring adanya pertumbuhan ekonomi dan bertambahnya pengetahuan 
masyarakat akan berbagai produk dan kualitas pangan meningkatkan tuntutan masyarakat akan adanya variasi dalam konsumsi. Faktor lain yang mempengaruhi konsumsi masyarakat terhadap komoditas pangan khususnya daging adalah kesukaan, pengalaman, agama, dan etnis (De Silva et al., 2010).

Mengingat begitu beragamnya faktor yang mempengaruhi konsumsi daging sapi dalam masyarakat, dan terkait dengan kepentingan pemerintah untuk mengatur keseimbangan konsumsi dan produksi dari daging sapi dalam rangka menjaga tingkat swasembada daging sapi di Papua Barat, maka perlu dilakukan kajian untuk mengetahui faktor apa saja yang mempengaruhi hal tersebut.

\section{MATERI DAN METODE Jenis dan Sumber Data}

Data penelitian yang digunakan bersumber dari data BPS, berupa data time series bulanan antara lain: data konsumsi daging sapi, data harga-harga produk yang diduga substitusi dan komplenenter terhadap konsumsi daging sapi, indek harga konsumen. Data berasal dari seluruh kabupaten di Provinsi Papua Barat, mulai tahun 1990 hingga tahun 2004.

\section{Metode Analisis}

Analisis data menggunakan regresi linear berganda. Dengan alat bantu analisis adalah perangkat softwear Eview 5. Hipotesis dalam penelitian ini adalah populasi penduduk, pendapatan per kapita, peningkatan harga daging ayam, daging babi, ikan, dan harga cumi, akan berpengaruh positif terhadap konsumsi daging sapi, sedangkan peningkatan harga beras dan ketela akan menurunkan konsumsi daging sapi. Dinyatakan dalam persamaan sebagai berikut:

$\ln Y_{d s}=\ln \beta_{0}+\beta_{1} \ln X_{1}+\beta_{2} \ln X_{2}+\beta_{3} \ln X_{3}+\beta_{4} \ln X_{4}+\beta_{5} \ln X_{5}+\beta_{6} \ln X_{6}+\beta_{7} \ln X_{7}$ $+\beta_{8} \ln X_{8}+\beta_{9} \ln X_{9}+\beta_{10} \ln X_{10}+\beta_{11} \ln X_{11}+\mu$

\section{Keterangan :}

$Y_{d s} \quad:$ Konsumsi daging sapi (kg/bulan)

$\begin{array}{lll}\beta_{1} \text { s/d } & : \text { Koefesien regresi peubah bebas } \\ \beta_{13} & & \\ X_{1} & : & \text { Populasi penduduk (jiwa) } \\ X_{2} & : & \text { Pendapatan (Income) riil perkapita (Rupiah) } \\ X_{3} & : & \text { Harga riil daging sapi (Rupiah) } \\ X_{4} & : & \text { Harga riil daging ayam (Rupiah) } \\ X_{5} & : & \text { Harga riil daging babi (Rupiah) } \\ X_{6} & : & \text { Harga riil telur ayam ras (Rupiah) } \\ X_{7} & : & \text { Harga riil telur ayam kampung (Rupiah) } \\ X_{8} & : & \text { Harga riil tongkol (Rupiah) } \\ X_{9} & : & \text { Harga riil beras (Rupiah) } \\ X_{10} & : & \text { Harga riil ketela (Rupiah) } \\ X_{11} & : & \text { Harga riil cumi-cumi (Rupiah) }\end{array}$

Seluruh nilai harga baik pendapatan dan harga barang adalah menggunakan data riil. Data riil diperoleh dengan jalan mendeflasikan harga/nilai berlaku dari setiap barang ke tahun dasarnya (Sukirno, 2002). Cara untuk mendapatkan harga riil untuk setiap komoditi adalah sebagai berikut :

Harga riil komoditi ke - i :



Keterangan :

$$
\begin{array}{ll}
\boldsymbol{K}_{i} & : \text { Harga riil komoditi ke - i } \\
H b K_{(i)(t)} & : \text { Harga berlaku komoditi ke - i } \\
& \text { pada tahun ke - n } \\
I h k K_{(i)(t d)} & : \text { Indek harga konsumen } \\
& \text { komoditi ke-i pada tahun } \\
& \text { dasar } \\
I h k K x_{(i)(t n)} & \text { Indek harga } \\
& \text { konsumen komoditi ke - i } \\
& \text { pada tahun n }
\end{array}
$$

Untuk menguji hipotesis persamaan di atas menggunakan Ordinary Least Square (OLS) dilakukan melalui dua tahap yaitu:

1) Pengujian terhadap asumsi-asumsi klasik, pengujian asumsi klasik yang dilakukan adalah pengujian terhadap kemungkinan adanyamultikolinearitas, heteroskedasitas dan autokorelasi dalam model regresi. 
2) Pengujian terhadap kesesuaian model (Greene, 1993; Widarjono, 2007). Untuk melihat kesesuaian model menurut Gudjarati (2003), digunakan koefisien determinasi $\left(R^{2}\right)$, Uji-F dan Uji-t sebagai berikut :

a. Koefesien determinasi $\left(R^{2}\right)$

Koefesien determinasi $\left(R^{2}\right)$ digunakan untuk mengukur kebaikan-suai (goodness of fit) dari persamaan regresi pada persamaan (1), yaitu memberikan proporsi atau prosentase variasi total dalam variabel dependen $(\mathrm{Y})$ yang dijelaskan oleh variabel independen (X) yang terdapat dalam model .

$R^{2}=(E S S / T S S)=1-(R S S / T S S)$

Keterangan :

$R^{2}$ : Nilai koefisien determinasi

ESS : Explain Sum of Square

TSS : Total Sum of Square

$R S S$ : Residual Sum of Square

Nilai $R^{2}$ selalu meningkat dengan bertambahnya variabel bebas. Untuk mengatasi hal tersebut digunakan adjusted $R^{2}$ dengan memasukkan derajat bebas agar kekurangan yang ditimbulkan dapat diatasi (Gudjarati, 2003).

$$
\text { Adjusted } \begin{aligned}
R^{2} & =1-[(R S S) /(n-k) /(T S S) /(n-1)] \\
& =1-[(R S S) .(n-k) /(T S S) .(n-1)] \\
& =1-\left(1-R^{2}\right) .(n-k) /(n-1)
\end{aligned}
$$

b. Uji-F (over-all test)

Uji $F$ dipergunakan untuk mengetahui pengaruh variabel independen secara bersama terhadap variasi variabel dependen.

Rumus hipotesisnya :

$H_{0}: \beta_{1}=\beta_{2}=\ldots=\beta_{i}=0$

$H a$ : salah satu $\beta_{i} \neq 0(\mathrm{i}=1,2,3 \ldots \mathrm{n})$

Untuk menguji kedua hipotesis tersebut dilihat dari nilai statistik $\mathrm{F}$ pada tingkat kepercayaan $(\alpha)$ sebagai berikut:

F-hitung $=\left[\left(R^{2}\right) /(k-1) /\left(1-R^{2}\right) /(n-k)\right]$

F-tabel $=[(k-1) ;(n-k) ; \alpha]$

Keterangan:

$\mathrm{k}$ : banyaknya koefesien regresi termasuk

\section{intersep \\ $\mathrm{n}$ : banyaknya sampel}

Kesimpulan untuk menerima dan menolak $\mathrm{H}_{0}$ adalah, jika $\mathrm{F}$ hitung $\leq \mathrm{F}$ tabel maka $\mathrm{H}_{0}$ diterima, artinya variabel independen secara simultan (bersama-sama) tidak berpengaruh nyata terhadap variabel dependen. Jika $\mathrm{F}$ hitung $>\mathrm{F}$ tabel maka $\mathrm{H}_{0}$ ditolak dan $\mathrm{Ha}$ diterima artinya variabel independen secara bersama - sama berpengaruh nyata terhadap variabel dependen.

\section{c. Uji-t (individual test)}

Uji-t dimaksudkan untuk mengetahui pengaruh variabel independen secara individual terhadap variabel dependen.

Kaidah hipotesisnya adalah :

$H_{0}: \beta i=0$, berarti tidak terdapat pengaruh variabel independen (Xi) terhadap variabel dependen.

$H a: \beta i \neq 0$, berarti terdapat pengaruh variabel independen $(\mathrm{Xi})$ terhadap variasi variabel dependen.

$\beta i$ dalam hal ini adalah koefesien regresi dari variabel independen dan intersep.

Untuk menguji kedua hipotesis tersebut dilihat dari nilai statistik $\mathrm{t}$ pada tingkat kepercayaan $(\alpha)$ sebagai berikut: $\mathrm{t}$-hitung $=\beta i / S \beta i$

$\mathrm{t}$-tabel $=(\mathrm{n}-\mathrm{k} ; \alpha / 2)$

Keterangan:

$\beta i$ : parameter yang diestimasi

$S \beta i$ : standar error parameter yang diestimasi

$\mathrm{k} \quad$ : jumlah variabel independen

Kesimpulan untuk menerima dan menolak $\mathrm{H}_{0}$ adalah, jika $\mathrm{t}$ hitung $\leq \mathrm{t}$ tabel maka $\mathrm{H}_{0}$ diterima, artinya variabel independen secara individual tidak berpengaruh nyata terhadap variabel dependen. Jika t hitung $>\mathrm{t}$ tabel maka $\mathrm{H}_{0}$ ditolak dan $\mathrm{Ha}$ diterima artinya variabel independen secara individual berpengaruh nyata terhadap variabel dependen. 
Tabel 1. Tingkat konsumsi daging sapi per kapita per tahun di Provinsi Papua Barat

\begin{tabular}{ccccc}
\hline Tahun & $\begin{array}{c}\text { Pemotongan } \\
\text { Sapi (ekor) }\end{array}$ & $\begin{array}{c}\text { Jumlah Penduduk } \\
\text { (jiwa) }\end{array}$ & $\begin{array}{c}\text { Produksi } \\
\text { (kg/tahun) }\end{array}$ & $\begin{array}{c}\text { Konsumsi Daging } \\
\text { Sapi } \\
\text { (kg/kapita/tahun) }\end{array}$ \\
\hline 1990 & 1.158 & 418.444 & 92.640 & 0,22 \\
1991 & 1.318 & 438.831 & 105.440 & 0,24 \\
1992 & 1.058 & 446.291 & 84.640 & 0,19 \\
1993 & 1.914 & 467.300 & 153.120 & 0,33 \\
1994 & 3.986 & 483.700 & 318.880 & 0,66 \\
1995 & 2.347 & 497.836 & 187.760 & 0,38 \\
1996 & 1.567 & 498.836 & 125.360 & 0,25 \\
1997 & 3.719 & 499.836 & 297.520 & 0,60 \\
1998 & 5.052 & 499.936 & 404.160 & 0,81 \\
1999 & 5.990 & 501.756 & 479.200 & 0,96 \\
2000 & 2.642 & 515.150 & 211.360 & 0,41 \\
2001 & 1.988 & 575.534 & 159.040 & 0,28 \\
2002 & 2.734 & 624.555 & 218.720 & 0,35 \\
2003 & 3.926 & 645.913 & 314.080 & 0,49 \\
2004 & 4.701 & 642.472 & 376.080 & 0,59 \\
Total & & & 6,73 \\
\hline Rerata Konsumsi Daging Sapi (Tahun $1990 \mathrm{~s} / \mathrm{d}$ 2004) (kg/kapita/tahun) & 0,45 \\
\hline
\end{tabular}

\section{HASIL DAN PEMBAHASAN}

Tingkat konsumsi daging sapi dan faktor-faktor yang mempengaruhi konsumsi daging sapi tertera pada Tabel 1, bahwa ratarata konsumsi daging sapi masyarakat Provinsi Papua Barat pada kurun waktu Tahun 1990 hingga 2004 adalah sebesar 0,45 $\mathrm{kg}$ per kapita per tahun. Walaupun level konsumsi ini masih dibawah rata-rata konsumsi nasional yang berada pada kisaran 1,7-1,8 kg per kapita per tahun namun tampak bahwa terjadi peningkatan konsumsi perkapita 2,43\% setiap tahunnya. Hal ini menunjukkan bahwa terjadi peningkatan pilihan masyarakat untuk mengkonsumsi daging sapi. Serupa dengan penelitian De Silva et al. (2010) terhadap konsumsi daging di Srilanka, hasil penelitian Sida dan Hwang (2007) tentang konsumsi daging di Korea Selatan, Huang dan Show (2010) pada masyarakat Taiwan yang mengindikasikan adanya peningkatan konsumsi daging seiring dengan waktu dan perubahan gaya hidup masyarakat di negara-negara tersebut.

Perhitungan regresi untuk mengetahui faktor-faktor yang mempengaruhi konsumsi daging di Papua Barat terlihat pada Tabel 2. Hasil analisis menunjukkan sekitar 96,28\% mampu dijelaskan oleh variabel penjelasnya, dan sisanya $3,72 \%$ dijelaskan oleh variabel lainnya. Variabel-variabel penjelas tersebut antara lain jumlah penduduk, pendapatan masyarakat per kapita, harga daging sapi, daging ayam, daging babi, telur ayam ras ayam kampung, cumi-cumi, ikan tongkol (cakalang), harga beras dan harga ketela.

Dari sekian peubah bebas yang diujikan terhadap tingkat konsumsi daging sapi masyarakat Papua Barat, jumlah penduduk, pendapatan, harga beras dan harga ketela merupakan variabel yang signifikan mempengaruhi konsumsi daging pada taraf kepercayaan $1 \%$, demikian pula harga daging ayam, harga daging babi, harga cumicumi berpengaruh signifikan pada taraf kepercayaan 5\%, dilanjutkan harga 
Tabel 2. Faktor-faktor yang mempengaruhi konsumsi daging Sapi di Provinsi Papua Barat

\begin{tabular}{|c|c|c|c|c|c|c|c|}
\hline Variabel independen & Notasi & TH & Koefesien & SE & t-ratio & \multicolumn{2}{|c|}{ p-value } \\
\hline Konstanta & $\beta_{0}$ & & -17.70514 & 7.062555 & -2.506902 & 0.02200 & \\
\hline Populasi Penduduk & $X_{1}$ & + & 1.631059 & 0.490813 & 3.323175 & 0.00380 & $* * *$ \\
\hline Pendapatan & $X_{2}$ & + & 0.564177 & 0.190197 & 2.966274 & 0.00830 & $* * *$ \\
\hline Harga daging sapi & $X_{3}$ & - & 0.230902 & 0.167329 & 1.379928 & 0.18450 & Ts \\
\hline Harga daging ayam & $X_{4}$ & + & -0.596287 & 0.2326 & -2.563572 & 0.01950 & $* *$ \\
\hline Harga daging babi & $X_{5}$ & + & -0.244654 & 0.088437 & -2.766415 & 0.01270 & $* *$ \\
\hline Harga telur ayam ras & $X_{6}$ & + & -0.062482 & 0.243464 & -0.256637 & 0.80040 & Ts \\
\hline Harga telur ayam kampung & $X_{7}$ & + & -0.324604 & 0.400134 & -0.811239 & 0.42780 & Ts \\
\hline Hargai ikan tongkol & $X_{8}$ & + & 0.107076 & 0.058382 & 1.834059 & 0.08320 & $*$ \\
\hline Harga beras & $X_{9}$ & - & -0.729551 & 0.247964 & -2.942169 & 0.00870 & $* * *$ \\
\hline Harga ketela & $X_{10}$ & - & 0.608536 & 0.108795 & 5.593401 & 0.00000 & $* * *$ \\
\hline Harga cumi- cumi & $X_{11}$ & + & 0.342955 & 0.159111 & 2.155446 & 0.04490 & $* *$ \\
\hline R-squared & 0.9769 & & & F-statistic & & 69.28865 & \\
\hline Adjusted R-squared & 0.9628 & & & DW stat & & 1.871277 & \\
\hline S.E. of regression & 0.0806 & & & Prob(F-stati & & 0.00000 & \\
\hline S.D. dependent var & 0.41803 & & & & & & \\
\hline $\begin{array}{l}\text { Prob. Chi Square of Breusch- } \\
\text { Godfrey Serial Correlation } \\
\text { LM Test: }\end{array}$ & 0.29529 & & & $\begin{array}{l}\text { Prob. Chi S } \\
\text { Heterosked }\end{array}$ & $\begin{array}{l}\text { e of White } \\
\text { ity Test: }\end{array}$ & 0.64759 & \\
\hline
\end{tabular}

\begin{tabular}{cllll}
\hline Keterangan: & $* * *$ & $:$ Signifikan pada $\alpha 1 \%$ & ts & $:$ tanda sifnifikan \\
& $* *$ & $:$ Signifikan pada $\alpha 5 \%$ & TH & $:$ tanda harapan \\
& $\bullet \quad:$ Signifikan pada $\alpha_{10 \%}$ & SE & $:$ standar error
\end{tabular}

Ikan - ikan tongkol (cakalang) berpengaruh terhadap konsumsi daging sapi pada taraf kepercayaan $10 \%$.

\section{a. Jumlah penduduk}

Tanda harapan (expected sign) untuk jumlah penduduk adalah positif. Hasil penelitian menunjukkan koefesien yang sesuai dengan tanda harapan, yang berarti peningkatan jumlah penduduk meningkatkan konsumsi daging sapi di Papua Barat. Hal ini sesuai dengan hasil penelitian De Silva et al. (2009) yang meneliti faktor-faktor yang mempengaruhi konsumsi daging sapi di Srilanka, dan juga hasil penelitian He et al. (2003) tentang beberapa faktor yang mempengaruhi permintaan beberapa produk daging (unggas, babi dan seafood) menunjukkan bahwa penambahan jumlah jiwa akan meningkatkan konsumsi daging sapi. Terkait hal tersebut maka dalam pengendalian konsumsi daging sapi, jumlah penduduk dapat dijadikan menjadi acuan dalam perencanaan produksi dalam rangka memperoleh keseimbangan permintaan dan penawaran daging sapi di Papua Barat.

b. Pendapatan

Hasil yang diharapkan dalam penelitian ini adalah bahwa peningkatan pendapatan masyarakat akan meningkatkan konsumsi daging. Tanda koefien pendapatan dalam penelitian ini adalah positif, menunjukkan fakta bahwa peningkatan pendapatan masyarakat Papua Barat akan meningkatkan konsumsi daging sapi. Hasil penelitian ini sesuai dengan hasil penelitian beberapa peneliti antara lain Hupkova et al. (2009), Hennebery dan Hwang (2007), menyatakan 
bahwa peningkatan pen dapatan masyarakat mempengaruhi gaya hidup mereka terhadap konsumsi. Pilihan konsumsi akan beralih pada pangan sumber-sumber protein hewani diban dingkan asal nabati. Protein hewani yang dimaksud di sini adalah daging sapi, daging babi dan daging unggas. Ditambahkan pula oleh Nielsen (2001), bahwa peningkatan pendapatan dan status sosial masyarakat Eropa akan meningkatkan konsumsi terhadap daging sapi.

\section{c. Harga daging ayam}

Tanda koefisien untuk variabel daging ayam dalam penelitian ini adalah negatif, hal ini berarti berlawanan dengan tanda harapan. Dugaan awal terhadap daging ayam adalah bahwa komoditi ini bersifat subtitusi terhadap daging sapi ternyata menunjukkan hasil yang sebaliknya, yakni menunjukkan karakter sebagai komoditi komplementer. Peningkatan harga daging ayam akan menurunkan konsumsi daging sapi. Hal ini diduga terkait dengan budget share masyarakat Papua Barat, dimana daging ayam sendiri merupakan komoditi yang relatif lebih sering dikonsumsi dibanding daging sapi, sehingga kenaikan harga daging ayam akan menurunkan kemampuan masyarakat untuk membeli daging sapi. Hasil penelitian ini serupa dengan hasil penelitian Sida dan Hwang (2007) yang meneliti proporsi belanja komoditi daging pada beberapa negara di dunia. Hasil penelitian menunjukkan bahwa peningkatan harga ayam secara signifikan akan menurunkan pilihan masyarakat Korea Selatan untuk mengkonsumsi daging sapi. Peneliti lain dengan hasil yang serupa dengan penelitian ini adalah hasil penelitian Amir et al. (2006), peningkatan harga daging ayam pada sebagian masyarakat terutama masyarakat berpendapatan menengah kebawah secara signifikan menurunkan konsumsi masyarakat terhadap daging sapi.

\section{d. Harga daging babi}

Variabel harga daging babi memiliki tanda koefesien yang berlawanan dengan tanda harapan. Kondisi ini diduga disebabkan bahwa masyarakat Papua Barat melihat baik daging babi ataupun daging sapi, merupakan satu kelompok pangan sumber protein tinggi yang dianggap setara satu sama lain. Sehingga terdapat kecenderungan bahwa apabila harga daging sapi naik, maka harga daging babi pun ikut naik. Hal ini terlihat dari perubahan harga setiap tahun dari dua komoditi ini pada Gambar 1 dan 2.

Terlihat bahwa terdapat kenaikan harga daging sapi dan babi secara bersama sama. Kondisi ini menciptakan situasi kompetitif harga antar kedua produk daging tersebut, sehingga masyarakat dengan batasan anggaran terbatas harus memilih salah satu dari kedua komoditi ini untuk dikonsumsi. Dengan demikian adanya kenaikan harga daging babi akan menyebabkan pilihan konsumsi daging sapi menurun. Hasil yang serupa dengan penelitian ini adalah hasil penelitian Sida dan Hwang (2007). Walau tidak signifikan namun ditunjukkan bahwa peningkatan harga daging babi di Amerika Serikat akan menurunkan konsumsi daging sapi di negara tersebut.

Peneliti lain yang memiliki hasil serupa dengan hasil penelitian ini adalah Huang dan Show (2010) menunjukkan hasil adanya sifat komplementer antara daging sapi dan daging babi di Taiwan secara signifikan. Hal ini dilihat sebagai akibat adanya kecenderungan masyarakat melihat kedua produk ini sebagai satu kelompok pangan sumber protein tinggi (high protein food). Disamping itu kedua komoditi ini dianggap memiliki flavor yang dikenali berbeda sehingga tidak mampu mensubtusi satu sama lain, sehingga untuk masyarakat yang favorit terhadap daging babi tetap akan memilih daging babi terlebih dahulu dibanding daging sapi sekalipun harga daging babi meningkat.

e. Variabel harga ikan tongkol dan cumicumi

Dalam penelitian ini baik ikan tongkol (cakalang) maupun cumi - cumi menunjukkan karakter sebagai komoditi subtitusi terhadap konsumsi daging sapi. Peningkatan harga ikan tongkol dan cumi cumi akan meningkatkan konsumsi terhadap 


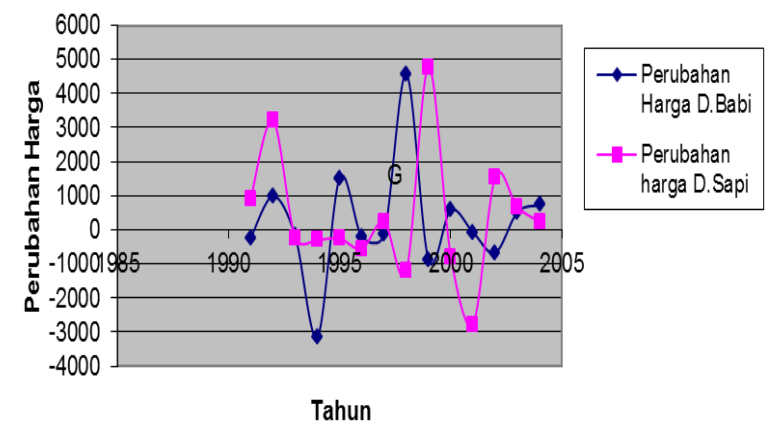

Gambar 1. Perubahan harga daging sapi dan babi tahun 1990 s/d 2004

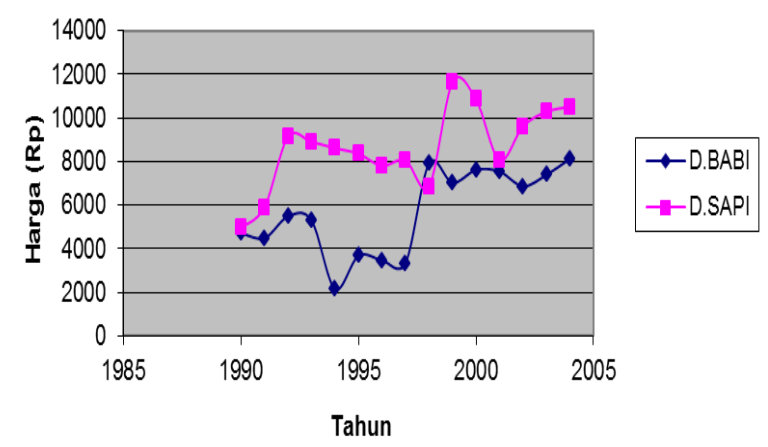

Gambar 2. Harga daging sapi dan babi tahun $1990 \mathrm{~s} / \mathrm{d} 2004$

daging sapi. Menurut He et al. (2003), Gossard dan York (2003) sifat pilihan konsumsi masyarakat terhadap jenis komoditi pangan tertentu dipengaruhi oleh status etnis dan pengalaman konsumsi masyarakat. Ditambahkan oleh Carthy et al. (2003) bahwa konsumsi masyarakat terhadap produk pangan dipengaruhi oleh kesukaan (eating enjoyment).

Lokasi Provinsi Papua Barat yang kebanyakan berada dekat pantai mempengaruhi karakter konsumsi mereka. Ikan laut segar menjadi menu favorit masyarakat ini. Tanpa menolak adanya keinginan untuk melakukan variasi konsumsi membuat ikan laut segar menjadi komoditi subtitusi dari daging sapi.

\section{f. Harga beras dan harga ketela}

Pada awal hipotesis dinyatakan bahwa beras diduga merupakan komoditi komplementer bagi daging sapi. Hasil penelitian menunjukkan hasil yang sesuai dengan tanda harapan/hipotesis. Peningkatan harga beras akan menurunkan konsumsi daging sapi. Hasil penelitian ini serupa dengan hasil penelitian Frichani dan Widodo (2006), serta Amir et al. (2006) yang menunjukkan bahwa peningkatan harga beras berpengaruh negatif terhadap konsumsi daging sapi. Hal tersebut dikarenakan daging sapi dikonsumsi bersama dengan beras.

Kondisi ini dapat pula dijelaskan dengan alasan lain, yakni menyadari keberadaan beras sebagai makanan pokok sumber energi yang sulit ditinggalkan. Oleh karena itu ketika terjadi peningkatan harga beras maka masyarakat akan memfokuskan keterbatasan anggaran belanjanya pada pemenuhan kebutuhan kalori terlebih dahulu dibanding kebutuhan protein hewani. Akibatnya peningkatan harga beras menurunkan kemampuan masyarakat untuk membeli daging sapi.

Terdapat kondisi yang sebaliknya terjadi pada peningkatan harga ketela. Ketika harga ketela meningkat konsumsi daging sapi juga meningkat. Hal tersebut menunjukkan bahwa ketela bukan komoditi komplementer terhadap daging sapi. Walau pangan sumber kalori bagi masyarakat Papua Barat adalah nasi dan ketela, tampaknya kedua jenis bahan pangan sumber kalori ini berbeda dalam sifat komplementernya. Daging sapi lebih banyak dikonsumsi dengan nasi daripada ketela. Sedang pasangan konsumsi ketela bagi masyarakat Papua kebanyakan adalah komoditi ikan laut. Terlihat dari hasil penelitian pada Tabel 2 bahwa ketela memiliki karakter yang sama dengan ikan tongkol (cakalang) dan cumi-cumi, yakni sebagai produk subtitusi bagi daging sapi. Ketika harga ketela dan komoditi pasangannya yakni ikan laut meningkat maka konsumsi daging sapi meningkat.

Terkait dengan perencanaan penyediaan daging sapi di Papua Barat dalam rangka memenuhi harapan pemerintah untuk mencapai kondisi kecukupan daging melalui pengendalian konsumsi dan diversifikasi, maka langkah yang dapat dilakukan untuk Papua Barat adalah melihat faktor yang paling berpengaruh terhadap peningkatan konsumsi daging sapi dan menggunakan faktor tersebut sebagai dasar kebijakan. Dalam penelitian ini jumlah penduduk 
merupakan faktor dominan berpengaruh terhadap peningkatan konsumsi daging sapi, sehingga langkah antisipatip pengendalian penyediaan (supply) perlu dilakukan menggunakan faktor jumlah penduduk ini. Perencanaan matematis yang melibatkan jumlah penduduk beserta trend perubahannya dapat menjadi alternatif dalam perencanaan penyediaan daging sapi di Papua Barat.

Faktor lain yang dapat menjadi dasar pengembangan kebijakan penyediaan daging sapi adalah dengan melihat komoditi lain yang bersifat subtitusi terhadap daging sapi. Dalam penelitian ini satu satunya komoditi yang bersifat subtitusi adalah ikan. Hal ini menyangkut preferensi masyarakat Papua Barat yang memang menyukai ikan. Namun mengingat jenis komoditi ini adalah ikan laut dimana ikan laut bukan dibudidayakan melainkan masih menjadi komoditi tangkapan sehingga ketersedian komoditi ini kurang terjamin, maka seyogyanya mulai dipikirkan pengembangan komoditi ikan laut secara budidaya tanpa mengurangi taste sebagai ikan laut .

Langkah lain terkait pengendalian penyediaan daging sapi agar tidak melampaui natural increase adalah mengembangkan sumber protein lain yang menjadi pesaing daging sapi. Demikian pula untuk daging ayam dan daging babi yang walau dalam penelitian ini tidak menunjukkan sebagai komoditi subtitusi bagi daging sapi, haruslah tetap dipertimbangkan untuk dikembangkan dalam rangka diversifikasi produk sumber protein hewani, terlebih analisa dari penelitian ini adalah dikarenakan faktor budget kompetitif dimana kenaikan harga daging ayam dan daging babi akan mengurangi konsumsi daging sapi. Perlu dilakukan kajian lebih lanjut untuk melihat preferensi masyarakat yang sesungguhnya terhadap sumber protein hewani. Hasil kajian mengenai preferensi masyarakat terhadap beberapa sumber protein dari yang paling disukai hingga kurang disukai dapat menjadi dasar pertimbangan terkait kepentingan melakukan diversifikasi sumber protein hewani. Kajian diversifikasi akan dapat digunakan untuk mengurangi beban penyediaan sumber protein hewani yang masih tertumpu hanya pada salah satu komoditas termasuk daging sapi.

\section{KESIMPULAN}

1. Rata-rata konsumsi daging sapi perkapita pertahun masyarakat Papua Barat adalah sebesar $0,45 \mathrm{~kg}$.

2. Peningkatan jumlah penduduk, pendapatan, harga ikan tongkol, harga cumi-cumi dan harga ketela akan secara nyata meningkatkan konsumsi daging sapi. Peningkatan harga daging babi, daging ayam dan beras secara nyata menurunkan konsumsi daging sapi.

\section{DAFTAR PUSTAKA}

Amir A., S. Widodo, S. Haryastuti. 2006. Analisi konsumsi daging sapi pada tingkat rumah tangga di Sulawesi Tengah. Jurnal Agrosaint. 19(4): 435449.

BPS 2009. Papua dalam Angka. 2009. Badan Pusat Statistik Provinsi Papua Papua Barat.

Charthy, M.Mc. de Boer, S.O. Reilly and L. Cotter. 2003. Factors influencing intention to purchase beef in the Irish Market. Meat Science, 65 (3), 10711083.

Direktur Jenderal Bina Produksi Peternakan Departemen Pertanian. 2003. Buku Statistik Peternakan. Departemen Pertanian, Jakarta.

De Silva P.H.G.J., N.S.B.M. Atapattu and A.L. Sandika. 2010. A Study of The Socio - Cultural Parameters Associated With Meat Purchasing and Consumption Pattern: A Case of Southern Province, Sri Lanka. The Journal of Agricultural Sciences, 5(2), 71-79.

Frichani,M., S. Widodo, 2006. Struktur Konsumsi Daging di Daerah Istimewa Yogyakarta. Jurnal Dinamika 
Sosial Ekonomi. 7(1). Di download dari : http://agriculture.upnyk.ac.id. Pukul 12.50 WIB

Gossard M.H, R. York. 2003. Social Structural Influences on Meat Consumption. Human Ecology

Review. 10(1): 1-9. Di download dari : www.humanecologyreview.org. pada tanggal 17 Juni 2011. Pukul 14.00 WIB.

Hupkova. D.P., Bielik, N. Turcekovia. 2009. Structural Change in the Beef Meat Demand in Slovakia and Demand Elasticity Estimation.Agri. Econ. Vol 8 :361-367. Di down load dari

http://www.agriculturejournals.cz. pada tanggal 18 Juni 2011. Pukul 12.05 WIB.

Hennebery S.R. and S. Hwang, 2007. Meat Demand in South Korea: An Application of the Restricted Source-Differentiated Almost Ideal Demand System Model. Journal of Agricultural and Applied Economics. 39(1), 47-60.

Ilham,N. Hastuti,S dan Karyasa, I.K., 2002. Pendugaan Parameter dan Elastisitas Penawaran dan Permintaan Beberapa Jenis Daging di Indonesia. JAE, 20.
Soedjana, T.D. 2005. Prevalensi Usaha Ternak Tradisional dalam Perspektif Peningkatan Produksi Ternak Nasional. Jurnal Litbang Pertanian, 24(1) : 10-14.

Suryana. 2009. Pengembangan Usaha Ternak Sapi Potong Berorientasi Agribisnis Dengan Pola Kemitraan. Jurnal Litbang Pertanian, 28(1): 29-37

Setyono.D.J., R. Maharani dan W. Rindayanti. 2003. Konsumsi Daging Sapi Segar Konsumen Rumahtangga di Pasar Tradisional. Med. Pet. 26 (1). Di download dari: http://e-jurnal.perpustakaan.ipb.ac.id tanggal 17 Juni 2011 pukul 14.00 WIB

Sukirno, S. 2002. Pengantar Teori Makro Ekonomi. Jakarta. Raja Grafindo Persada. Jakarta.

Witt, U. 2001. Learning to consume : Theory of wants and the growth of demand. Journal of Evolutionary Economics 11: $23-36$

Widarjono, A. 2007. Ekonometrika: Teori dan Aplikasi. Untuk Ekonomi dan Bisnis. Ekonesia. Fakultas Ekonomi Universitas Islam Indonesia. Yogyakarta. 